\title{
The rise and fall of Christian-Nationalism: The ideological evolution of Dopper intellectuals
}

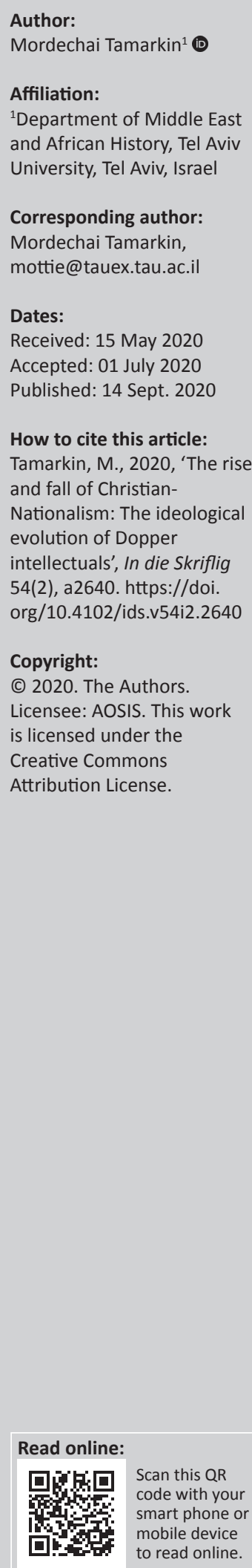

Christian-nationalism as the core of Afrikaner identity and ideology was introduced by Dopper intellectuals. It was used by them as early as the late 19th century. The two components of this concept were, in fact, an oxymoron. Christianity represents universal values, whereas nationalism focuses on the particular identity and interests of a particular group, the nation. Consequently, there was a built-in tension in this identity and ideological construct. For Dopper intellectuals, the Christian was clearly paramount. Nationalism had to be submitted to God's universal moral values.

Keywords: Christian-nationalism; Apartheid; Dopper intellectuals; Afrikaanse Calvinistiese Beweging; Woord en Daad; Potchefstroom University for Christian Higher Education; Reformed Church of South Africa.

\section{Introduction}

Until the 1948 electoral victory of the National Party (NP), the potential contradiction between Christian universal morality and Afrikaner nationalism rarely surfaced. Dopper intellectuals were in the forefront of the Afrikaner nationalist struggle. The struggle of the Afrikaners for national self-assertion did not contradict God's design or Christian values.

After 1948, in the eyes of Dopper intellectuals, the balance between the two began to weigh too heavily on the side of nationalism. As Afrikaner nationalism in power became increasingly tainted by apartheid, Dopper intellectuals began to distance themselves from it. Their notion of apartheid was clearly different from that of the NP government. The reality shaped by their government and its conception of Christian-nationalism and of apartheid became too sharp for them. Consequently, their criticism against both mounted. During the 1980s, young Dopper intellectuals divorced themselves altogether from Christian-nationalism, identifying themselves merely as Christians.

In this article I do not deal with the Reformed Church (Gereformeerde Kerk [GK]) but rather with intellectuals, most of whom were members of this church and of Potchefstroom University (Potchefstroom University for Christian Higher Education). They acted in the public sphere, not as members of the church but rather as members of the Afrikaner civil society.

The article is based on an analysis of the evolution of the relevant discourse of the objects of this study. This discourse was about the appropriate relations between universal Christian moral values, like love and justice, and nationalism, which prioritised the nation to the detriment of the others.

The gist of the article relates to a debate among scholars about the nature of nationalism. Radical scholars tend to view nationalism as inherently evil. Nationalism, for them, stands in stark contradiction to universal secular moral values. There are, however, other scholars for whom nationalism represents a broad moral spectrum (Tamarkin 2000:129-152). For them, nationalism, imbued with the right dose of universal values, was capable of being a force for moral good. Liberal nationalism represents such a benevolent secular ideological construct. From this perspective, Christian-nationalism was a fine example of such a benevolent ideological cohabitation of the universal and the particular. 


\section{Dopper intellectuals as articulators and inculcators of the idea of Christian-Nationalism until 1948}

The origins of the group of intellectuals who are the objects of this study can be traced back to the Theological School in Burgersdorp in the late 1890s. ${ }^{1}$ When it was relocated to Potchefstroom in 1905, the main centre of their operation was the Theological School, which was the nucleus from which the Potchefstroom University for Christian Higher Education developed.

These intellectuals were motivated by their strong Calvinist beliefs. A central feature of their Reformational doctrine was the immanence of God, whose presence was not confined to the church. He was, indeed, present in every sphere of human activity. It was, therefore, the calling of the true believer to bring his message, in its Reformational interpretation, to every sphere of human activity. They saw it as their mission to try and shape society in the image of their 'life and world view'. Their relevant society, which was their sphere of endeavour, was the Afrikaner volk. This was the field they were called to cultivate. This disposition instilled in them a tremendous drive to serve their volk in every sphere.

The literature pertaining to the evolution of the Afrikaners during the 20th century attributed to Dopper intellectuals a very important role in the history of their people through 1948. Their main contribution in the ideological field was the articulation of the ideology of Christian-nationalism. However, before 1948 they functioned not only as articulators of an ideology, but they were also very active in inculcating it to their people. Furthermore, they were prominent in promoting the social, cultural, economic and political development of the Afrikaners. As such, they played a pivotal role in the evolution of the Afrikaner civil society, which made a significant contribution to the 1948 electoral victory of the National Party.

In adhering to Christian-nationalism, they were inspired by a parallel concept adopted by the neo-Calvinist antirevolutionary movement in Holland in the 19th century. Because in Holland the national issue was not divisive, the Dutch movement aimed mainly at preserving their religious doctrine and way of life according to the cannons of Dort. In South Africa, unlike Holland, the preservation of the 'life and world view' of the Dopper intellectuals was closely linked to ethnonational survival. This was so because the pressure of British imperialism and the English culture threatened not only their nationality but also their religious life. Thus, the survival of Calvinism in South Africa depended also on Afrikaner national survival. This enticed a strong nationalist response among Dopper intellectuals.

1The Theological School of the Gerformeerde Kerk [Reformed Church] was (1869. It came under strong Afrikat Church was istablished in Burghesdorp in 1869. It came under strong Afrikaner nationalist influence mainly through the influence of Jan Lion Cachet and the intensifying conflict between the Republican Afrikaners and the British Empire, which culminated in the Anglo-Boer War, 1899-1902.
This was manifested as early as the late 19th century among students of the GK Theological School in Burgersdorp. They were inspired by Professor Jan Lion Cachet, an early Dutch convert to Afrikaner nationalism. The student J.D. du Toit (Totius) wrote the following in the students' magazine on the eve of the Anglo-Boer war: 'Do not forget then, if we do not clutch our hand and tooth firmly to our nationality, also in the church, we are lost.' ('Vergeet dan nie as ons hand en tand vas hou aan ons nasionaliteit, ook in die kerlike, is ons verlore'). (Van der Vyver 1969:85).

After it moved to Potchefstroom in 1905, the Theological School continued to be the hub of Afrikaner Christiannationalism. Dopper intellectuals were very active in the movement for Christian national education (CNO) (Hexham 1981:151-164) and in the triumphant second language movement, which entrenched Afrikaans as the national language of the Afrikaners (Hexham 1981:129-141). A quotation from Het Kerkblad, the mouthpiece of the Reformed Church, in 1905 captured the various strands in the Dopper intellectuals' nationalist endeavour: 'We struggle for the preservation of Afrikanerdom, our nationality, our Religion and our Language' (Hexham 1981:132).

Dopper intellectuals were also behind Herzog when he founded the National Party in January 1914 (Giliomee 2003:370). In fact, the programme of principles of the party was written by Dirk Postma, a Dopper, along clear Christian national lines. When in 1934 Malan founded the Gesuiwerde Nasionale Party (GNP), the Dopper intellectuals rallied to his side (Vachter 1965:57).

The influence of the Potchefstroom Dopper intellectuals before 1948 stemmed largely from their capture of the leadership of the Afrikaner Broederbond in the late 1920s. They transformed a rather rudderless and ineffectual freemason-like organisation into a formidable power house whose influence stretched to all corners of Afrikaner society. This they were able to do mainly through the FAK (Federasie van Afrikaanse Kultuur Veriniginge - Federation of Afrikaans Cultural Unions), which they cultivated. The Afrikaner Broederbond, under their leadership, mobilised and guided the emerging Afrikaner civil society. This enabled them to exert tremendous influence on their people (Bloomberg 1989:41, 82-83; O'Meara 1983:60-61; Serfontein 1978:33, 79). The Afrikaner Broederbond, under Dopper intellectuals' leadership, guided the Afrikaner civil society along Christian national lines (Bloomberg 1989:54-62).

For the Dopper intellectuals, the essence of Christiannationalism was that of Afrikaner nationalism guided by the word of God. However, especially in the late 1930s and during the Second World War, Afrikaner nationalism was tainted by extreme, chauvinistic ideas with origins in neoFichtianism and Nazism. However, the supremacy of the volk and the adulation of a Fuhrer stood in stark contradiction to the Dopper adherence to the absolute sovereignty of the Almighty and his universal moral values. Such extreme ideological importations were an abomination to many Dopper intellectuals. 
These new ideological waves affected the fortunes of the Dopper intellectuals within Afrikanerdom. From the late 1930s, they began to lose their grip on the movement they had helped to found and develop. New actors and new ideas challenged and began to replace them. By 1948 they had lost all the influence they had had before.

\section{From priests to prophets: Dopper intellectuals from 1948 to 1990}

Scholarly works relating to the post-1948 period largely ignored the Dopper intellectuals. Hermann Giliomee, in his monumental book on the 'biography' of the Afrikaners, hardly mentioned them. Yet, it is my firm conviction that especially in the sphere of political, ideological and moral discourse, they continued to play a remarkable role. Their post-1948 story is very rich not only in written output but also in the manifestation of the human spirit in unfavourable circumstances. Whereas until 1948 they acted as priests in the march of the Afrikaners to national assertion and political power, in the post-1948 period they assumed the role of prophets scrutinising their government and their volk using the scriptural compass that guided them.

Having witnessed the triumph of their nationalism and their party in power after 1948, Dopper intellectuals began to have second thoughts about their cherished Afrikaner nationalism. Morally, Afrikaner nationalism in power appeared increasingly less attractive. For many Afrikaner nationalists, the balance between the Christian and the national was shifting towards the latter. This was manifested in the policy of the NP government towards non-white people. Apartheid, conceived by the NP government as a means to ensure Afrikaner national survival, could not square with the Dopper intellectuals' commitment to the universal moral values of the scriptures.

This was unacceptable to the Dopper intellectuals because it infringed on the sovereignty of God and his moral values. S. du Toit wrote the following (Du Toit 1959):

It can be that there are Afrikaners who exaggerate the idea of nationalism and make a religion of it at the cost of true religion. This is as objectionable as cosmopolitanism. (p. 2)

Coetzee lamented that nationalism had degenerated into naked chauvinism and racism and that loyalty to the party was placed higher than loyalty to God and his commandments (Coetzee January 1959:6). Bingle came out strongly against the deification of nationalism: 'In our nationalism there cannot be a sanctification of the national' (Bingle 1957:4-6). Du Plessis was also clear: 'As much as it is important to assert the existence of the nation, the Kingdom of God cannot take second place. The foremost obligation is to obey God' (Du Plessis 1960:1).

In the 1960s and the 1970s, as Dopper intellectuals became increasingly critical of the manifestations of Afrikaner nationalism in power, Christian-nationalism was becoming the focus of much debate and criticism among them. In February 1965, Woord en Daad published an article comparing 'positive nationalism' and 'exaggerated nationalism', which was increasingly totalitarian and exclusive, infringing on the principle of sphere sovereignty (Woord en Daad February 1967:11). Clearly, it was an implied criticism on the state of post-1948 Afrikaner nationalism in power.

\section{Young Dopper intellectuals join the ideological debate}

In the early 1970s, a group of young Dopper intellectuals began to sound a more radical voice in the discourse of Afrikaner nationalism. They did it in their short-lived publication Loog. One of their targets was the national myth of Afrikanerdom. De Klerk, a historian, opposed the usage of history as a means to inculcate Afrikaner jingoism. He came out strongly against the sanctification of the national past (De Klerk October 1971:8-9). An editorial proposed the detachment of nationalism from Christianity (Loog May 1972:2-3). This was an attack on the essence of the prevailing perception of Afrikaner Christian-nationalism. Potgieter lamented that politics was too much the politics of identity (Potgieter June 1972:6-7). Du Plessis hailed the 'new Afrikaners' who were engaged in the 'de-glorification of the Afrikaners and their history' (Du Plessis March 1972:5).

This shift from ethnonational particularism to Christian universalism was manifested in the 1976 Afrikaanse Calvinistiese Beweging congress, held in the wake of the Soweto riots and dedicated to 'Justice in the South African society'. The most scathing critique of Afrikaner nationalism was uttered by Van der Vyver (1977):

On the scale of values, Christian justice occupies a higher place than our white skins, our Afrikaans language and cultural heritage. And if the conditions of our survival cannot square with the demands of justice then the White civilisation deserves to be destroyed. (p. 82)

This morally critical spirit imbued the 1977 Koinonia Declaration, which was issued by young Dopper intellectuals from Potchefstroom and a group of English-speaking Christians from Germiston. In it the government was severely censured for injustices suffered by black people. The signatories urged the government 'to submit to the demands of the Word of God so that it will not be necessary for us to disobey their authority' (Koinonia Declaration, 1.4.2, 16.11.1977).

\section{The triumph of Christian morality}

During the 1980s, young Dopper intellectuals withdrew even more from their Afrikaner identity and ideological laager. Their discourse was now more strictly Christian. They were preaching universal Christian morality to the detriment of Afrikaner nationalism. Du Plessis, Van Wyk, Vorster and Van der Walt were dominant voices in this discourse. Their views on the predicament and destiny of Afrikanerdom were strongly impacted by the demands of Christian morality. 
Du Plessis played a crucial role in this discourse especially as editor of Woord en Daad in the first half of the 1980s. In his thinking there was a definite shift from the volk to the individual and through the latter to the universal. In dethroning the volk and crowning the individual human being, Du Plessis went back to the act of creation. The nation, he argued, was not part of the order of creation. It was one of the historical phenomena that occurred under God's grace. God created Adam and Eve rather than nations. Furthermore, nations were created not in order to maintain their identity but rather to be a blessing to one another. Nations were also transient, 'nations come and go and our citizenship in the Kingdom of God is eternal' (Du Plessis 1980:24). Thus, the existence of the nation did not enjoy a normative status anymore. Du Plessis, in a sense, deprived the volk of its transcendental raison d'être (Du Plessis 1983):

The identification of God's interest with politics which is contaminated by sin and by any action by a people or a race only causes damage to the Kingdom of God. (p. 3)

Thus, the Afrikaners were relieved of their calling as guardians and propagators of Christian civilisation in the southern tip of Africa (Du Plessis 1983):

The existence and survival of Christianity ... is nowhere in the world - and also not in South Africa - dependent on the existence of a certain people or race and its worldly power position. (p. 3)

Van Wyk, a theologian, was also lured by his Christian moral convictions into the political arena. For a Dopper intellectual, believing in the immanent God and in his duty to serve him in all spheres of human activity, the political field could not be left unattended. Politics, from this perspective, was not an autonomous field. It had to be inspired and directed. 'Wise politics', he argued, had to serve God and his kingdom rather than man and his ideals. 'Stupid' politics was one in which 'man and his struggles took the place of God's Kingdom' (Van Wyk 1983:13).

Politics, guided by God's commandment to love, had to be imbued with justice and righteousness. Justice was one of the characteristics of the kingdom of God. From this perspective, the goal of the believer was 'survival in justice' rather than mere national survival. Justice was a manifestation of the commandment to love in the political field. Thus, in the context of the state, justice overrode law and order, as much as they were important. Justice in the political field meant that every human being (without reference to race or nationality) could 'experience to the full his God-given rights as a state citizen' (Van Wyk 1984:5). On the road to political justice, political selfdenial was 'the highest form of self-preservation' (Van Wyk 1984:6), whilst 'sinful self-assertion' was 'the surest form of self-destruction' (Van Wyk 1984:17). Political justice paved the way to reconciliation, leading to the removal of guilt and injustice (Van Wyk 1984). Thus, universal morality was the friend rather than the foe of true nationalism.

Van der Walt, a philosopher, was another young intellectual who made a significant contribution to the Dopper intellectuals' moral discourse, mainly in the second half of the 1980s. He viewed the social and political reality through the lenses of the scriptures. In an editorial in Woord en Daad, he chose Psalm 72 as his moral guidance. From it he learnt that a government was lawful only as long as it fulfilled God's will and moral values. According to this psalm, the king had to serve the people and not the other way around. He had to provide the people, particularly the poor and the oppressed among them, with justice. He also had to deliver them from oppression and violence. Clearly, this was not a description of the ethnocentric conduct of the NP government. By implication, at least, it was unlawful (Van der Walt 1986:2-4).

Van der Walt also entered the problematic field of human rights as opposed to collective national rights. Dopper intellectuals could not accept the prevalent secular human rights discourse because of its source of authority, namely, human beings and their inherent natural rights. Hence, he preferred human rights as stipulated by the Reform Ecumenic Synod of 1984 and approved by the South African Reformed Church Synod in 1985. These applied, of course, to all South Africans irrespective of race or nationality (Van der Walt 1987 [i]:32-37).

In the following year he called on the youth to get involved in politics and see it as a calling. Their calling was to serve God therein. Worshipping God, he argued, was not limited to the church. An important part thereof related to the way 'we think and act as citizens of this country'. The current politics, he argued, was unacceptable and 'our calling is to change it so that we could serve God also in politics'. He believed that 'if we will fulfil our calling as youth, we will have a tomorrow' (Van der Walt 1987 [ii]:1-4).

Vorster, a minister of religion and a theologian, also contributed to the Dopper intellectuals' discourse in the 1980s. He was a practising minister of religion who joined the staff of the Theological School only in 1990. Being a minister of religion, he viewed the church as an important agent in preparing believers for the impending radical change in their lives. There was an urgent need to re-educate society and prepare it for a new dispensation that would reflect sound Christian moral principles. The church, he believed, had not only the calling but also the capacity to undertake this challenging educational task through preaching.

He outlined an agenda for re-education through preaching, which, he believed, had an important role in changing negative dispositions in society (Vorster 1985:113-117). Love and justice, the good old Christian values, must be preached. Believers must be urged to seek justice and righteousness. This applied, obviously, mainly to the white people, who wielded power (Vorster 1985:113-117).

This shift of emphasis from a particular ethnocentric identity discourse to a broader moral one was reinforced by a reinterpretation of the Afrikaner national mythology. This was manifested in calls to change the nature of the Day of the 
Covenant, the prime date in the Afrikaner national calendar. Even Coetzee, who in his youth must have celebrated this festive day of national commemoration with great enthusiasm, now called for making it less offensive to black people and more unifying. He urged his readers to use it not to consecrate the past but rather to reconstruct the future (Coetzee December 1984:8-14). Similarly, the younger Elaine Botha wished that the celebration thereof would become a symbol of reconciliation rather than alienation (Botha 1988:5).

Clearly, Dopper intellectuals were becoming increasingly critical of Afrikaner ethnocentricity. Indeed, some of them were contemplating a new broader alternative identity befitting the changing circumstances. Du Plessis was exploring the African dimension of Afrikaner identity (Du Plessis 1987:16-17). Under his editorship of Woord en Daad, Van Jaarsveld, the famous and controversial Afrikaner historian, was asked to contribute an article probing the prospect of a common South African patriotism for all population groups (Van Jaarsveld 1983).

There was, as we have seen, also a shift from the volk to the individual. Helberg argued that God was concerned with the needs of the individuals rather than with those of groups. To underline the shift from the collective to the individual, he urged his readers to consider Christ's words, 'Love God as much as you can and love thy neighbour as you love yourself' (Heberg 1987). Consequently, the nation lost its role as an agent for the appropriate moral order.

Thus, the particular ethnonational identity that had been the bedrock of Afrikaner political world view was under strong attack from both the universal (God's word) and the particular individual (born in the image of God). This enabled, indeed forced, Dopper intellectuals to seek new meanings and new foundations for their individual and collective identity and self-perception. Unity in diversity was the prime principle underpinning the policy of apartheid. They now opted clearly for the unity of all South Africans, rejecting diversity, which had been the main raison d'être of the political dispensation implemented by the NP and of their own 'ideal' apartheid.

From this point of view, renouncing apartheid was both natural and indispensable. In essence, apartheid was the strategy of Christian-nationalism. It was purported to enable Afrikaners to maintain and protect the Afrikaner nationalist and neo-Calvinist island in the midst of a turbulent and threatening black sea. Once the sea was not perceived anymore as threatening, and once they opened their minds and hearts to the broader reality, there developed an increasing urge to become part of a post-apartheid South Africa as an integral part of black Africa as a whole.

Their Afrikaner identity did not die. They still spoke Afrikaans, read Afrikaans literature, went to Afrikaner churches, preached their ideas in Afrikaans and continued to love hunting and braaivleis. However, their nationalism suffered a severe coma. It is beyond the scope of this article, but it seems that paradoxically their sense of ethnocultural collective identity recovered, at least to some extent, from the coma, in post-apartheid South Africa. As Lourens du Plessis said unashamedly, 'I feel Afrikaner now more than before' (interview with Lourens du Plessis 2011).

\section{Conclusion}

As we have seen, from the point of view of Dopper intellectuals, there was an inherent tension between the two components of Christian-nationalism. The Christian represented an eternal, pure and immutable set of moral axioms that were at the root of their spiritual being. The nation, on the contrary, was terrestrial and historical. It represented an ethnocultural community potentially capable of the moral best or worst. They were deeply attached to it by virtue of history, culture and blood. In the wake of the Anglo-Boer war, the tension between the two was minimal. They were part of the historical collective underdog struggling for their freedom, honour and welfare. It was, in their view, a morally just cause and struggle and they were fully committed it.

After 1948, Afrikaner nationalism in power did not stand up to Dopper intellectuals' Christian moral standards and expectations. Consequently, the tension between the two sources of its authority was exacerbated. As devout Calvinists, their loyalty was primarily to their Calvinist 'life and world view'. Consequently, the moral discourse of the Dopper intellectuals weighed heavily on the side of Christian morality. During the 1980s, a younger generation of Dopper intellectuals was able to make the final break with their nationalism. They were able to look forward to a new postapartheid South Africa. It promised to relieve them from a heavy moral burden. Furthermore, there was the expectation of participating in one of the greatest political-moral experiences of the century. They could hardly resist these godly moral sirens.

\section{Acknowledgements Competing interests}

The author declares that he has no financial or personal relationships that may have inappropriately influenced him in writing this research article.

\section{Author's contributions}

M.T. is the sole author of this research article.

\section{Ethical considerations}

This article followed all ethical standards for research without direct contact with human or animal subjects.

\section{Funding information}

This research received no specific grant from any funding agency in the public, commercial or not-for-profit sectors. 


\section{Data availability statement}

Data sharing is not applicable to this article as no new data were created or analysed in this study.

\section{Disclaimer}

The views and opinions expressed in this article are those of the author and do not necessarily reflect the official policy or position of any affiliated agency of the author.

\section{References}

Bingle, H.J.J., 1957, Christelik-Liberaal, Nasionaal-Christelik en Christelik-Nasionaal Studiestuk, nr. 1, Instituut vir die Bevordering van Calvinisme, Potchefstroom.

Bloomberg, C., 1989, Christian nationalism and the rise of the Afrikaner Broederbond in South Africa 1918-1948, Indiana University Press, Bloomington and Indianapolis, IN.

Botha, E., 1988, 'Waarheen met Geloftedag 1988', Woord en Daad, Desember, pp. 4-6.

Coetzee, J.H., 1959, 'Gedagtes oor nasionalisme', Woord en Daad, Januarie, p. 2.

Coetzee, J.H., 1984, 'Geloftedag: Gister, vandag, more', Instituut vir Reformatoriese Studie, studiestuk, nr. 264, Desember, p. 5, Potchefstroom Universiteit vir Christelike Hoër Onderwys, Potchefstroom.

De Klerk, P., 1971, 'Die geskiedenis bied geen skuiling', Loog, Oktober, p. 8.

Du Plessis, H., 1960, 'Nasionale ontwaking en die Koningryk van God', Woord en Daad, 21 Oktober, pp. 1, 5.

Du Plessis, L.M., 1972, 'Die "nuwe Afrikaner"', Loog, Maart, p. 5.

Du Plessis, L.M., 1980, 'Die politieke betrokkenheid van die universiteit', Instituut vir die Bevordering van Calvinisme, reeks F1, studiestuk, nr. 147, Maart, Potchefstroom.

Du Plessis, L.M., 1983, 'Die keuse op 2 November 1983', Woord en Daad, Oktober, pp. 2-4.

Du Plessis, L.M., 1987, 'Ex Africa', Woord en Daad, Januarie, pp. 1-25.

Du Toit, S., 1959, 'Onaantasbare nasionalisme', Woord en Daad, November, p. 2.

Giliomee, H., 2003, The Afrikaners: Biography of a people, University of Virginia Press, Charlottesville, VA.
Heberg, J.L., 1987, 'Christenkap,veelvolkigheid en die komende verkiesing', Kerkblad, 22 April, pp. 36-37.

Hexham, I., 1981, The irony of Apartheid: The struggle for national independence of Afrikaner Calvinism against British imperialism, The Edwin Mellen Press, Lewiston\ Queenston \Lampeter.

Koinonia Declaration, 1977, J.J. Venter (Pontie) Private Papers.

Loog, 1972, 'Loog, Christelik-Nasionaal?', Nie meer nie, Junie, pp. 2-3.

O'Meara, D., 1983, Volks-kapitalisme: Class, capital and ideology in the development of Afrikaner nationalism, 1934-1948, Raven Press, Johannesburg.

Potgieter, P.J.J.S., 1972, 'Roeping en identiteit', Loog, June, pp. 6-7.

Serfontein, J.H.C., 1978, Brotherhood of power: An exposition of the secret Afrikaner Brotherhood, Indiana University Press, London.

Tamarkin, M., 2002, 'The moral ethnicity of scale: Titular nation-states and political order in the former Communist realm', Tel Aviver Jahrbuch fur deutsche Geschichte XXX (2002), Ethnizitat, moderne enttraraditionalisierrung, Universitat Tel Aviv, Wallstein Verslag, Tel Aviv.

Vachter, W.H., 1965, White laager: The rise of Afrikaner nationalism, Pall Mall Press, London.

Van der Vyver, G.C.P., 1969, My erfenis is vir my mooi, Kalvyn Jubileum Boekefonds, Potchefstroom.

Van der Vyver, J.D., 1977, 'Die juridiese faset van geregtigheid in die Suid-Afrikaanse samelewing', Instituut vir die Bevordering van Calvinisme, reeks $F$ \& I, Potchefstroom Universiteit vir Christelike Hoër Onderwys, Potchefstroom.

Van der Walt, B.J., 1986, 'Psalm 72: A commandment for the government to rule according to the will of God', Woord en Daad, September, pp. 2-4.

Van der Walt, B.J., 1987, '(i) Etiek en mensregte', In die Skriflig 21, 81.

Van der Walt, B.J., 1987, '(ii) God het 'n more vir die Christenjongmense in SuidAfrika', Instituut vir die Bevordering van Calvinisme, reeks F, studiestuk nr. 246-247, Potchefstroom Universiteit vir Christelike Hoër Onderwys, Potchefstroom.

Van Jaarsveld, F.A., 1983, "n Gemeenskaplike patriotisme vir alle bevolkingsgroepe in Suid-Afrika', Woord en Daad, Oktober, pp. 5-6.

Van Wyk, J.H., 1983, 'Gesprek oor linkse en regse politiek', Woord en Daad, September, pp. 12-13.

Van Wyk, J.H., 1984, 'Etiek en politiek', Instituut vir die Bevordering van Calvinisme, studiestuk, nr. 29, September.

Vorster, J.M., 1985, 'Kerk en politiek: Die roeping van die kerk in die Suid-Afrikaanse politieke problematiek', in J.H. Van Wyk en J.M. Vorster (eds.), Altyd reformeer: Besinning oor politiek en godsdiens, pp. 113-117, Altyd Reformeer, Braamfontein

Woord en Daad, 1967, 'Lewenbeskoulike begrippe', Februarie, p. 11. 